\title{
Tax Collection in Northern Ghana during British Colonail Rule (1898 - 1950)
}

\author{
Maasole, Cliff \\ Department of Social, Political and Historical Studies \\ University for Development Studies, Wa Campus, Ghana \\ DOI//http://dx.doi.org/10.4314/gjds.v14i2.14
}

\begin{abstract}
One of the key issues in European Colonial history, whether British, French or German, has been the policy of taxation. This study examines the history of the introduction of taxation in the Northern Territories at the outset of British colonial rule in the last decade of the nineteenth century. The work considers the nature of taxation, methods employed in the collection of the tax, the expenditure and the effects of taxation on the traditional social life of the people. The delay and temporal abolition of taxation had dire consequences for Northern Territories. Archival material was obtained in the Public Records and Administration Department both in Accra and Tamale. Information was obtained through oral interviews with elderly people of Northern extraction. Information was also gathered from some chiefs and educationists who hail from the area, and from University dons who have provided written material about the area. Other relevant secondary source material, such as from books, enriched the study. The study found out that the British imposed levies on the caravan transit trade. English metallic currency and cowries were used and payment could also be made in kind. Notwithstanding the problems concomitant with direct taxation, the British went ahead to introduce and implement the policy. The conclusion is that the ensuing difficulties this engendered, such as protestations from colonial officials, led to the abolition of direct taxation and even the collection of levies on the transit trade.
\end{abstract}

Keywords: Administrative History, Protectorate, Transit Trade, Direct Taxation, District Commissioners

\section{Introduction}

The principle of taxing the inhabitants of overseas colonies and protectorates as a means of raising revenue was common with all the European Empires in Africa. The British, French and German colonial administrators recognized the necessity that some form of taxation, whether direct or indirect, had to be imposed on the local people. This was for the purposes of making the colonies and protectorates to pay their way since the policies 
governing the financial relations between the colonial powers and their overseas territories embodied a system of financial autonomy for the latter (Rotberg, 1967; Suret Canale, 1971). It was commonly held that the taxation of Africans was the cornerstone upon which European rule could be built (Lugard, 1965). It not only reinforced the assertion of the Whiteman's rule over the African, but also provided the means by which social services could be initiated. In Northern Territories, the first Chief Commissioner and Commandant, Lt. Col. Henry P. Northcott, considered the early imposition of direct taxation on the people as a "convincing proof of paramountcy" of the British presence, and as "the essence of easy rule over the natives" ${ }^{\text {"14. }}$. Not only were the natives to be made to realize that they must contribute as far as their means allowed, towards the finances of the Protectorate, they were to be acquainted with the principle of a constant direct taxation at the very inception of British rule. Various scholars such as Brukum (1996) and Beinng (1975) have discussed taxation in Northern Territories in connection with the respective problems they have investigated. However, no attempt has been made to give it a detailed treatment within the context of administrative history during the period of colonial rule in the area. This article focuses on the subject of taxation by considering the nature of taxation, the methods employed in collecting the taxes since these often constituted the key factors in the successful implementation of tax schemes, expenditure and the effects of taxation on the traditional social life of the people. The delay and temporal abolition of taxation had dire consequences for the people of Northern Territories.

This article has been divided into two parts, for the main reason that there were two phases to taxation in Northern Territories. The first phase was from 1898 to 1930. During this period the British administration pursued a haphazard and half-hearted policy on taxation. In these years, the colonial regime could not take a firm decision or stand on what kind of taxes it would impose on Northern Territories until 1930 when a clear tax policy was formulated for the area. This latter date marked the beginning of the second phase in which direct taxation was systematically imposed under a system of native administration based on the principles of indirect rule. The early 1930s therefore saw the systematic imposition of a uniform tax which contrasted sharply with the ill-defined policy of the earlier phase.

The dates 1898 and 1950 have also been chosen for the following reasons. The former marks the introduction of direct and indirect taxation in Northern Territories under the British colonial administration. Although the direct tax was abolished shortly afterwards, it was re-introduced in the 1930s. In 1950, the existing tax system in Northern Territories became merged with Local Council rates after Local Councils were 
introduced as administrative institutions. The first part of the article will therefore deal with the early efforts of the British administration to levy direct and indirect taxes on the peoples of Northern between 1898 and 1930.

\section{Early Attempts at Taxation}

When Northcott arrived in Northern Territories in 1898 he found no instances of the inhabitants paying direct or indirect taxes. No regular or recurrent direct taxation existed among the centralized and the non-centralized peoples in pre-colonial times. A form of tribute did exist in Dagbon, Mamprugu, Gonja and among the Wala. This was as yet unknown to the British as the administration did not take time to study the political and social institutions of the local people. The British therefore had no precedents upon which to base an alien tax structure. However, Northcott was convinced that the opportune moment to impose a tax on the people was the beginning of colonial rule in the area ${ }^{15}$. Thus in 1898 he decided to introduce both direct and indirect taxation in Northern Territories.

The decision to levy taxes was partly motivated by the principles outlined above and partly by the peculiar position of the then Northern Territories Protectorate which became Northern Ghana after the Gold Coast regained independence in $1957^{16}$. The British had imagined that the North was rich in mineral and natural resources as the Colony and Asante; and that a booming commerce already existed in the area. These visions of optimism soon gave way to feelings of forebodings when reports on the area indicated that it lacked exploitable mineral and natural resources ${ }^{17}$. As the territory was progressively opened up and administratively unified, it became evident that its chief commerce lay in the transit caravan trade that passed through the area. The hopes of a self-supporting protectorate rapidly diminished and the Colonial Office was forced to turn to parliament for grants - in - aid in order to finance the administration of the Northern Territories.

The grants-in-aid were meager and were grudgingly given (Kimble, 1965). They in fact ceased after 1900, throwing the protectorate's finance onto the Gold Coast Government. It was this precarious financial position of the newly created protectorate which led Northcott to institute first, indirect and then direct taxation in the area as a means

15 Ibid.

16 It was not made an integral part of the Gold Coast administratively and could not therefore benefit directly from the resources of Asante and the Colony.

17 PRAAD, Accra, Hodgson to Chamberlain, August $29^{\text {th }} 1899$ on expenditure on the Northern Territories and Mr. Antrobus' minutes on the financial position in the Northern Territories. 
of raising revenue to supplement subventions from the central government to the protectorate.

\section{The Nature of the Caravan Transit and Local Trade}

In 1898, Northcott began levying import duties on the caravan trade. This transit trade was controlled by Moshie traders from Burkina Faso and had two aspects to it. The south bound trade consisted largely of livestock such as, cattle, sheep, goats, fowls, donkeys and horses. Various patterns of Moshie cloth were included and there was also a tiny amount of salt. No figures were kept for the livestock in the early years of British rule in the area but the traffic was estimated to be a large one. The trade in cloth was inconsiderable but it was nevertheless an important commodity considering the regularity with which it was imported into the Northern Territories ${ }^{18}$.

The transit trade moving northward, north-eastwards and eastwards to countries such as Burkina Faso and beyond, northern Togoland, Benin and Northern Nigeria consisted almost entirely of kola nuts although there was also a small export trade in salt ${ }^{19}$.

The caravans were in charge of remarkably few men in comparison to their sizes. A large mixed caravan, consisting of cattle, sheep and goats together with donkeys with panniers to be filled with kola nuts were driven along by ten to fifteen men and few accompanying boys and women. The traders bought nothing except food stuff while they were on their way down to places such as Salaga, Kintampo and Techiman, and returned almost exclusively with kola ${ }^{20}$.

Apart from the transit trade, there were two categories of local trade: the one by the local peoples and trade by strangers from outside the Northern Territories. The trade by the local peoples involved items such as rice, maize, guinea corn, millet, yams, groundnuts, okro, pepper, beans and dawadawa ${ }^{21}$. Such items of trade indicated that the people were mainly agriculturalists. There was some indigenous weaving but on a small scale. The people made very little income from this local trade, but their needs were also small.

The trade by strangers to Northern Territories was carried on mainly by Hausa traders, Yorubas, Akan and the Kotokoli. This trade was made up of the sale of meat, Moshie and Kotokoli cloths, Hausa knives and leather products, brass and iron bracelets, iron discs for conversion into hoes, salt, some cheap European cloths and lead crystals for

\footnotetext{
18 PRAAD, Accra, ADAM 56 /1/131, Report on Trade in the Northern Territories by A. Balstone, June $26^{\text {th }} 1911$.

19 Ibid.

20 Ibid.

21 Ibid.
} 
darkening women's eye lashes ${ }^{22}$. It was, however, the transit trade that was taxed and not such trade as existed in the hands of locals and non-locals. Settlements in the Tamale populated by itinerant traders developed into what is today referred to as Moshie and Hausa Zongo respectively because traders of these ethnic origins usually rested at such places before continuing their journey.

The duties imposed on the items of the transit trade were as follows: 5 shillings per horse, 3 shillings per cow, 2 shillings per donkey, 6 pence per sheep and goat and 2 shillings per head - load of merchandise. For each donkey-load, the tariff was set at 4 shillings. The tax was levied on animals and loads intended for sale and yielded $£ 248: 14$ shillings in the three months from October to December, 1898 (Crowder, \& Obaro, 1970).

Administrative stations were established at places such as Gambaga, Salaga, Wa, Bole and Kintampo where small but increasing amounts were collected ${ }^{23}$. This was the first Government tax in colonial Northern Territories, but as a form of indirect taxation, it was not entirely new to the Moshie traders. The local chiefs already levied tolls on the caravans that passed through their areas and appropriated the proceeds to themselves ${ }^{24}$. What, however, was new about the tax was its method of collection.

The tariffs were imposed in consultation not with the local chiefs but with the Imams or for instance, the Hausa High Priest at Gambaga and the leaders of such Moshie traders who happened to be in Gambaga at the time. The collection of the tax was therefore confined to the Imams who then handed over the proceeds to the British Administrative Officers at each town. The administrative officers recorded the sums of money paid to him and issued receipts to the traders to enable them avoid paying duties again at any other station through which they might pass. Only English currency was accepted in payment of the tax. In towns where metallic currency was not yet in use, cowries were taken and then converted into English money. ${ }^{25}$ In exceptional cases, however, payment in kind was accepted and the proceeds sold and credited to the Government. The Imams who collected the tax were rewarded directly by the British administration. So they became the paid agents of the Government in the matter of collecting the $\operatorname{tax}^{26}$.

The local chiefs therefore played no part in the collection and administration of the tax and although the collection of the tax went on smoothly, the methods employed hardly suited the more important tax which Northcott intended imposing on the whole area.

\footnotetext{
22 Ibid.

23 Northcott, Report on the Northern Territories, p. 181.

24 Ibid.

25 Ibid.

26 Ibid.
} 


\section{Hints at the Introduction of Direct Taxation and its Ramifications}

During his tour of the Protectorate in 1898 and 1899, Northcott explained to the inhabitants the benefits of British rule and the need for the introduction of a direct tax. At every village of importance that he passed through, the people were told of the advantages of direct taxation and were then informed that they would be required to pay an annual tax towards the cost of administering their country ${ }^{27}$. It was a oneman campaign intended to prepare the grounds for the introduction of the tax. It was effective in so far as no opposition was raised against the tax but Northcott was no doubt aware of the difficulties that lay ahead.

Administratively, British Colonial rule in the Northern Territories was still at the infant stages and lacked the necessary personnel for the effective collection of the tax. There were still large areas of the North not yet brought under British rule and it would be difficult to ensure compliance by the inhabitants to pay the tax. Moreover, the imposition of direct taxation required a general census of the population which, with the limited numbers of officers that Northcott had, could not be effectively carried out for the assessment of the tax. Yet, in spite of these problems, Northcott went ahead and introduced the tax in 1899. He estimated that it would yield about $£ 875$ at the first collection but that this would be progressively increased in the course of the succeeding years $^{28}$.

The nature of the tax itself was unclear. It was neither a hut tax nor a poll-tax. In the case of the hut tax, the owners of the huts were required to pay a fixed amount annually on each hut to the Government. (Lugard, 1965). Such a tax did not exactly correspond to the house rate since there could be several huts in a household, depending on the locality and the type of houses or compounds built by the inhabitants. As regards the poll tax, the levy was on every adult person who paid a specified amount per year (Lugard, 1965).

Northcott's tax had neither of these characteristics. Instead of assessing the tax on houses, huts or on individuals, lump sums were allotted to towns and districts as shown below:

\footnotetext{
27 Information gathered from the late Professor B. G. Der, University of Cape Coast, Department of History, $20^{\text {th }}$ March 2013.

28 Ibid.
} 


\begin{tabular}{|l|l|}
\hline Town or District & Amount to be Paid \\
\hline Mamprugu & $£ 200$ \\
\hline FraFra & $£ 50$ \\
\hline Dagarti & $£ 100$ \\
\hline Daboya & $£ 25$ \\
\hline Tumu & $£ 200$ \\
\hline Wa & $£ 100$ \\
\hline Bole & $£ 100$ \\
\hline Kintampo & $£ 50$ \\
\hline
\end{tabular}

\section{Figure 1: Lump sums allocation to towns and districts}

Source: PRAAD, Accra. C. O. 879/58, Enc. In No. 79, Northcott to Colonial Secretary, $4^{\text {th }}$ March, 1899

The distribution of the tax was not based on the population of the towns. For example, Mamprugu which was a whole state was to pay the same amount as Tumu which was only a town. Similarly, FraFra, a densely populated district, would pay the same amount as the town of Kintampo, while Dagarti, another ethnic district would return an amount equal to those of the towns of Wa and Bole. There was no mention of the Dagomba paying the tax but Northcott no doubt hoped that these anomalies in the assessment of the tax would eventually be rectified as the British gained more knowledge of the area and its peoples. Looking at the figures, however, it can be said that the criteria upon which Northcott based the tax was trade. Tumu, Wa, Bole and Gambaga were all important trading towns in pre-colonial Northern Territories.

Northcott therefore felt their inhabitants were wealthier, capable and would easily pay the tax. With the exception of Tumu and Daboya, all these towns were also administrative centres where the British had already introduced metallic currency. Their inhabitants could therefore afford to pay the tax in English money. Lower amounts, however, were allotted to Kintampo and Daboya for the reason that their trade had recently been destroyed during the raids of Samouri and Babatu. The tax itself yielded slightly more than Northcott had estimated. Some £9oo was collected in place of the $£ 875,{ }^{29}$ but to the British administration, the acceptance of direct taxation as a principle by the Northern people was more significant than the revenue obtained from it at this stage of British rule in the area. The British administrators learnt the lesson that Northerners were more amenable to taxation than their neighbours to the South and this experience was fully exploited in later years in the imposition of a more general direct tax on the North. 
Unlike the tax on the caravan trade with which the local people had little to do, the direct tax affected them directly as it had to be paid by them. Its collection needed the full cooperation of the chiefs and not that of the Imams and Hausa traders who had no political authority over the people. The collection of the tax was therefore entrusted in the hands of the chiefs. In the areas where the District Officers were in direct touch with the chiefs, they were allocated the amounts to be collected, and the chiefs in turn distributed the allocations to their sub-chiefs and headmen. These latter agents then had the sums redistributed among the heads of households. The heads of households shared the amount allotted to them among the adult males of their compounds and collected the money from them ${ }^{30}$.

Working in the reverse process, the ordinary male adult who paid the tax gave his money to his household head who in turn gave it to his head chief who handed it over to the District Officer. This latter officer then paid all the sums collected into Government chest and recorded the amounts in his monthly and quarterly books ${ }^{31}$.

In areas where the British were not in direct contact with the traditional rulers, the method of collecting the tax was slightly different. Officers of the then Northern Territories Constabulary were sent out with columns of soldiers to the various villages equipped with orders to contact the chiefs and require them to collect the tax from their subjects. These Constabulary Officers who were usually native in the area, went to the traditional chiefs in the villages and had them collect the tax from their people which they took back to the District Officer ${ }^{32}$. If the chiefs were unable to collect the tax on the spot, the columns went back to the administrative headquarters, while the chiefs collected it and sent it to the Officer Commanding the district through their representatives ${ }^{33}$. By these methods, the British were able to enforce the payment of the tax but it was soon abolished owing to some difficulties encountered by the Administrative Officers such as the small number of administrative personnel.

\section{Abolition of Taxation and the Consequences}

Although introduced without any opposition, the officers commanding the districts observed during its collection that the tax generated discontent among the inhabitants. The chiefs, it was also noted, used the tax as a means of extorting money from their

\footnotetext{
30 Interview with Robert Wiedong at Nandom. He is about One Hundred years old, $15^{\text {th }}$ May, 2013.

31 Ibid.

32 PRAAD, Accra, ADM 56/1/416, Monthly Reports, Black Volta District Reports for January, February, March and April, 1901.

33 Ibid. Reports for May, 1901.
} 
subjects for themselves. ${ }^{34}$ In some areas too, attempts to collect the tax proved impracticable owing to lack of staff.

Administrative posts had not yet been opened in Western Dagbon. There, it proved almost impossible to attempt to collect the tax in towns such as Savelugu, Tamale, Kumbungu and Tolon. A similar situation existed in the extreme North-East where it was impossible to collect the tax in places such as Navrongo, Sandema, Zuarungu and Bawku which were administered by a small staff based at Gambaga which was the headquarters of the Northern Territories Protectorate before 1907. The expenses on the collection of the tax were also unduly high in proportion to the revenue obtained. These problems were not insurmountable and would no doubt have been solved with the consolidation of British rule over Northern Territories. But Northcott's successor, Major A. H. Morris, felt uneasy about the discontent that the tax aroused among the people and dropped it at the end of 1901 in favour of compulsory labour..$^{35}$ In 1907, the tax on the caravan trade was also abolished on the grounds that it tended to reduce the trade that passed through Northern Territories and to drive the Moshie traders into the hands of the Germans in Northern Togo. ${ }^{36}$ After 1907, therefore, direct taxation and the indirect tax on the caravan trade ceased to exist in Northern Territories as sources of revenue.

As an attempt to attract more trade from the Moshie traders the measure was a success. This caravan trade rapidly increased in volume after 1907, but Northern Territories benefited very little from it. The large numbers of cattle, sheep and goats that passed through the Protectorate to Salaga, Yeji, Attebubu, Bole and Kintampo for onward dispatch to Kumasi and Colony markets attracted no duties. In 1916, for instance, 77,656 cattle and 109,056 sheep and goats passed through the Protectorate without the traders paying any tax on them ${ }^{37}$. Government revenue in the Northern Territories fell sharply as a direct consequence of the abolition of the tax on the transit trade. It dropped from $£ 18,046$ in 1907 to only $£ 3,500$ in 1908 . During the next five years the disparity in revenue and expenditure was as follows:

34 Interview with the Bambale-wura, a sub-divisional chief in the Kpembe Division, Eastern Gonja, Salaga, $4^{\text {th }}$ June, 2013.

35 PRAAD, Tamale, Report on the Northern Territories for the year 1901, Nathan's Dispatch, $14^{\text {th }}$ April, 1902.

36 PRAAD, Tamale, Annual Report on the Northern Territories for the Year 1908, Acting Governor Bryan's Dispatch, $27^{\text {th }}$ May, 1909.

37 PRAAD, Accra, ADM 56/1/486, Annual Report, Northern Territories, 1916, P. 3. This Report noted the considerable increase in trade. In the North-West, 31,902 cattle passed through Wa in 1916, compared with 15,766 in 1915. The increase was 16,136. 
Figure 2: Disparity in revenue and expenditure (1909 - 1913)

\begin{tabular}{|l|l|l|}
\hline YEAR & REVENUE & EXPENDITURE \\
\hline 1909 & $£ 1,690$ & $£ 69,169$ \\
\hline 1910 & $£ 1,806$ & $£ 5,232$ \\
\hline 1911 & $£ 2,426$ & $£ 65,085$ \\
\hline 1912 & $£ 2,994$ & $£ 78,984$ \\
\hline 1913 & $£ 3,709$ & $£ 82,419$ \\
\hline
\end{tabular}

Source: Annual Report on the Northern Territories from 1908 to 1913

While revenue remained at an extremely low level, expenditure rose steadily and was far in excess of the former. During these and subsequent years, revenue came from meager sources such as market and slaughter-house fees and court fines. After 1925, additional revenue was derived from ferry-tolls following the introduction of mechanical transport into the North.

The basic reason for this regret was that it has come to light through investigations that the District Commissioners were conducting into the political and social systems of the northern people that in states such as Mamprugu, Dagbon and Gonja, a kind of levy already existed in the form of tribute paid to the chiefs and Paramount Chiefs. The Governors at Accra tended to regard the protectorate as a drain on the Colony's finances and were therefore reluctant to have large sums voted towards its development. ${ }^{38}$

\section{The Debate on the Re-introduction of Taxation}

The financial and economic stagnation the Northern Territories led an Acting Chief Commissioner, Major R. A. Irvine to suggest in 1909 that direct taxation be reintroduced in the form of either a hut tax or a poll tax. ${ }^{39}$ There was some regret in the Northern Territories administrative circles that direct taxation had been dropped and Lt. Col. A. H. Morris himself was of the opinion that his own action had been premature. ${ }^{40}$ The Administration therefore felt that it had not only been justified in imposing a direct tax but that it could use such knowledge as a basis for the reintroduction of the tax.

The proposal to levy a hut or poll tax aroused considerable debate between the District Commissioners and the Acting Chief Commissioner. The advantages of a tax in either of these forms were well noted. The collection of a hut or poll tax would place the finances

38 Information from Professor Raymond B. Bening, University of Ghana, Legon, Department of Geography and Resource Development, $13^{\text {th }}$ November, 2013.

39 PRAAD, Accra, ADM 56/1/87, Hut or Poll Tax, NTS, Correspondence.

40 PRAAD, Tamale, Colonial Office, 96/382, Morris to Governor, dated $12^{\text {th }}$ July, 1901. In Nathan's Dispatch to Chamberlain on the decision to abolish the tax after 1901, dated $22^{\text {nd }}$ August, 1901. 
of the Protectorate on a better footing and more money would be made available for the institution of social services. The tax would also stimulate an urge for more money and therefore compel the natives to work during the off-farming season or engaged in more viable trading enterprises. ${ }^{41}$

On the other hand, the District Commissioners were unanimous in their opinion against the tax. The objections they raised to it were similar to the problems encountered by Northcott, i.e. there would be considerable difficulty in collecting the tax with the small administrative staff available; it was practically impossible to take a census of the population in the whole of the British Protectorate of the Northern Territories upon which such a tax could be adequately assessed. The only way of collecting the tax would be through the chiefs but the District Commissioners feared that if its collection was left in the hands of the chiefs, they would use it as a pretext to enrich themselves at the expense of their subjects. ${ }^{42}$

There were other reasons, which in the view of the District Commissioners, militated against the imposition of a hut or poll tax. They feared its unpopularity might lead to a rebellion against British rule ${ }^{43}$. The absence of coinage in the remote parts of Districts meant that the tax would have to be paid in kind, a method of payment which one District Commissioner observed, "would be a vexatious burden and unprofitable to ourselves"44. There was also a moral argument that if the tax was not being imposed on the entire Gold Coast, it would be unjust and an unnecessary hardship to levy it on the poorest part of the country which was least able to pay it. ${ }^{45}$ Under the circumstances most of the District Commissioners felt that the time was not yet ripe for the introduction of a tax, the collection of which would be difficult and which would not offset the Administrative cost in terms of revenue.

A small poll tax levied on all adult males might have been easier to collect if properly supervised. The French already levied such a tax in neighbouring Burkina Faso even though it had to be collected in many places by armed force. ${ }^{46} \mathrm{~A}$ hut tax, on the other hand, would have been unequally distributed and burdensome to some areas. The

41 PRAAD, Accra, ADM 56/1/87, S. D. Nash, District Commissioner at Wa to Ag. Chief Commissioner of the Northern Territories, $17^{\text {th }}$ December, 1909. In 1907, when a civil administration was established in the NTS the Officers Commanding the Districts were redesignated District Commissioners.

42 PRAAD, Accra, ADM 56/1/87, T. H. Dugan D. C. Lawra, to his Provincial Commissioner, dated $14^{\text {th }}$ December, 1909 He expressed his views against the tax.

43 Ibid. Hah to Chief Commissioner, $17^{\text {th }}$ December, 1909.

44 Ibid. Regionald Palmer, D. C. Bawku, to his Provincial Commissioner $24^{\text {th }}$ September, 1909.

45 Ibid. A. J. Berthon, D. C. Salaga to his Provincial Commissioner, Tamale $11^{\text {th }}$ December, 1901.

46 Ibid. A. J. Berthon, D. C. Salaga to his Provincial Commissioner at Tamale, $14^{\text {th }}$ December, 1909. 
traditional houses of the Dagomba, Mamprusi and Gonja were round huts, and a man owned more than one hut if he had several wives and a family. In the NorthWest of Ghana, houses were rectilinear in form with flat mud roofs and few huts were incorporated in the buildings. In the North-East, the traditional buildings were also round in form but as in the North-West, they had few thatch roofed huts (Labelle, 1969). These architectural differences would have reflected in the distribution of a hut tax. The greater proportion of such a tax would have fallen on the Dagomba, Gonja and the Mamprusi and the other ethnic groups who lived in nucleated round hut compounds and villages. By its very nature too, the tax would have been a graduated one. A man who owned five or six huts in a compound would have to pay more than one who owned less even though the extra huts might be inhabited by his wives and children (Collin, B., 1975). In this method of assessment, therefore, the tax was bound to be more burdensome on some men than on others.

These implications in a hut tax in so far as the Northern Territories was concerned were not foreseen either by the District Commissioners or the Acting Chief Commissioner when he advocated for introduction of the tax. They no doubt would have revealed themselves against the tax in its operation if it had been imposed but the most compelling reason for the rejection of a hut or poll tax by the District Commissioner was the fear that a direct tax in whatever form would be a poor substitute for forced labour, disguisedly called free labour, in the area. ${ }^{47}$

\section{The Introduction of Compulsory Labour in Place of Direct Tax}

Compulsory labour had replaced direct taxation in 1901 and the Administrative Officers used it extensively in the construction of government buildings and roads. Large numbers of carriers were drafted into conveying goods both within and between administrative centres at no cost to the Government. Some of the District Commissioners were, therefore, quick to realize that if the proposed tax was levied, there would be no justification for requesting labour from the people. Apart from this, Labourers would want to be paid for any work done. ${ }^{48}$ Since the yield of the tax and the money voted might be insufficient to meet such requirements, the District Commissioner preferred the continuance of this forced labour to any form of direct taxation. As one District Commissioner observed, "if the proposed tax was levied I consider that this free labour would not be forthcoming and thus a far greater expenditure would have to be incurred to keep the Northern Territories in the way in which they are now kept"49.

\footnotetext{
47 PRAAD, Accra, ADM 56/1/87, Louis Castellain, D. C. Bole to the Ag. Chief Commissioner, $14^{\text {th }}$ December, 1909.

48 Ibid.

49 PRAAD, Accra, ADA 56/1/87, Nash to Ag. Chief Commissioner, $17^{\text {th }}$ December, 1909.
} 
Some improvement might have been made in the Protectorate's financial position if the Administration had reverted to imposition of indirect tax on the transit trade, which was much easier to collect. The insistence of the French authorities on coinage in payment of the poll tax in Burkina Faso stimulated an increase in the caravan trade. It caused the Moshie traders to pass through the protectorate in large numbers to sell their cattle, sheep and goats in order to obtain the necessary money to pay the tax. Consequently, the trade in cattle, sheep, goats, kola and salt increased enormously. ${ }^{\circ}$ After September, 1914, the rest of the Northern Territories came under British rule with the capture of the German territories in the area by a combined force of British and French troops. ${ }^{51}$ The entire trade which then passed through the Northern Territories came under the British so that the question of diverting trade into foreign hands no longer existed. It seemed reasonable then that the tax on the caravan trade could be reimposed without any risk of losing that trade to another colonial power. Yet that step was not taken with the result that revenue rose to its pre-war level owing to an increase in the market and slaughter-house fees and the addition of ferry tolls as an important source of revenue. Expenditure, however, still outstripped revenue. In the financial year $1927 / 28$, revenue was $£ 22,286$ while expenditure amounted to $£ 111,868$. In 1930 , revenue rose to $£ 24,574$ but expenditure was $£ 140,132^{52}$.

The close of the 1920 s saw slight increases in revenue but sources were still meager. This did not permit of any local improvements for the benefit of the people. In other words this situation did not inure to the material benefit of Northern people. By the early 1930 s the financial position of the Protectorate had reached a stage where further progress was impossible without increases in revenue. Such revenue had to be in a sufficiently constant form to permit the preparation of estimates with a reasonable hope that they would be realized. Lugard's dictum that 'No system of rule can be effective - whether governmental or municipal - unless it enjoys some measure of financial independence' was beginning to dawn on the administrative officers. While some of them were of the view that a direct tax in one form or another would alone provide the means whereby the additional revenue required for local development could be obtained, others were still opposed to a system of direct taxation which they felt would be an unfair discrimination against the North ${ }^{53}$.

50 Ibid. Report on the North-West Province, 1909, by S. D. Nash. See especially the section on trade.

51 PRAAD, Accra, Report on the Occupation of Yendi, Togoland Operations, Clifford's Dispatch to Secretary of State, $24^{\text {th }}$ September, 1914 .

52 PRAAD, Tamale, Annual Reports on the Northern Territories for 1927/28 and 1930/31.

53 PRAAD, Tamale, Northern Territories Report, Jones to Colonial Secretary. Dated $5^{\text {th }}$ November, 1934 , Memorandum on Direct Taxation in the Northern Territories, p. 2. 
It was not until the early part of 1929 that the Chief Commissioner, Arthur Henry WalkerLeigh, reluctantly accepted the Governor's suggestion that serious consideration should be given to the possibility of imposing direct taxation in the Northern Territories. But even then, Walker-Leigh took no steps towards the realization of the Governor's suggestion. He considered direct taxation as a definite evil involving a breach of faith with the northern peoples and calculated to injure their interests and to impair their relations with the colonial Government.

\section{Conclusion}

The British colonial Administration began taxation in the Northern Territories with the imposition of levies on the caravan transit trade. The collection of this tax rested in the hands of foreign traders. It was paid either in the form of English metallic currency or cowries and when payment was in kind the proceeds were sold and paid into government coffers. Trading activities engaged by the local inhabitants and foreigners were not taxed. It was the intention of the British Administration to eventually introduce direct taxation. This was championed by Lt. Col. H. P. Northcott, the first Chief Commissioner and Commandant of the Northern Territories of the Gold Coast. Notwithstanding the myriad of problems this would entail, he went ahead with its introduction. This affected the local inhabitants of the Northern Territories directly. Its collection differed fundamentally from that of the caravan trade as it involved the Chiefs, British Officers and the Northern Territories Constabulary. Lapses soon emerged in the collection of the tax such as administrative difficulties and by the opening of the twentieth century both direct taxation and the collection of the levies on the caravan trade were abolished in Northern Territories with dire consequences. Some of the colonial officials soon realized they were in error as regards the abolition but there was division among them in respect of the re-introduction of taxation. For instance, District Commissioners fiercely resisted the return of taxation as a poor substitute for forced labour that had been instituted earlier. It is concluded that the decision not to return to taxation in whatever form remained unhelpful to the financial predicament in the Northern Territories until the early 1930 s.

\section{References}

Baker, Collin. (1975). Tax collection in Malawi: An administrative history, 1891-1972. International Journal of African Historical Studies, Vol. 8, No. 1, pp. 40-62.

Furguson, P. and Ivor Wilks. (1970). "Chiefs, constitutions and the British in Northern Territories" In Crowder Michael and IKime Obaro (ed.) West African chiefs. African Publishing Corp. 
Kimble, D. (1963). A political history of Ghana. Oxford: Clarendon Press.

Lugard, F. D. (1965). The dual mandate in British Tropical Africa, (5 ${ }^{\text {th }}$ ed.). London: Frank Cass.

Rotberg, I., Robert. (1967). The rise of nationalism in Central Africa: The making of Malawi and Zambia 1873-1964. Harvard University Press.

Suret-Canale, J. (1971). French colonialism in Tropical Africa 1900-1945. London: C. Hurst. 